\title{
KUALITAS NUTRISI AMPAS KELAPA (Cocos nucifera L.) FERMENTASI MENGGUNAKAN Aspergillus niger
}

\section{NUTRITIONAL QUALITY OF FERMENTED COCONUT DREGS USING Aspergillus niger}

\author{
Heri Kurniawan*, Ristianto Utomo, dan Lies Mira Yusiati \\ Fakultas Peternakan, Universitas Gadjah Mada, Yogyakarta, 55281
}

Submitted: 24 December 2014, Accepted: 8 September 2015

INTISARI

\begin{abstract}
Penelitian ini bertujuan untuk mengetahui pengaruh penggunaan Aspergillus niger untuk fermentasi ampas kelapa (Cocos nucifera L.) terhadap kualitas nutrisi ampas kelapa. Aspergillus niger yang diperoleh dari Laboratorium Biokimia dan Nutrisi Fakultas Peternakan UGM, Yogyakarta dioptimalisasi pada substrat minyak kelapa dan ampas kelapa (AK). Variabel yang diamati antara lain produksi enzim lipase, kualitas fisik ( $\mathrm{pH}$, tekstur, warna, bau), dan komposisi kimia ampas kelapa tanpa kukus (AKTK), ampas kelapa kukus (AKK), ampas kelapa fermentasi (AKF) dan ampas kelapa kukus fermentasi (AKKF). Hasil penelitian menunjukkan Aspergillus niger menghasilkan enzim lipase tertinggi pada inkubasi hari ke empat baik pada substrat minyak kelapa $(0,85 \mathrm{U} / \mathrm{ml})$ maupun ampas kelapa $(1,81$ $\mathrm{U} / \mathrm{ml}$ ). Perlakuan pengkukusan maupun fermentasi AK berpengaruh terhadap $\mathrm{pH}$, tekstur, warna, bau dan terjadi penurunan bahan kering (12,75 dan 16,24\%), lemak kasar (13,11 dan 29,20\%), bahan organik (5,21 dan $16,89 \%)$ serta peningkatan protein kasar $(11,84 \%)$, serat kasar $(24,85$ dan $36,81 \%)$ dan bahan ekstrak tanpa nitrogen (10,28 dan 23,97\%). Berdasarkan hasil penelitian ini, dapat diambil kesimpulan bahwa Aspergillus niger memiliki aktivitas lipase yang cukup tinggi sehingga dapat menurunkan kandungan lemak ampas kelapa.
\end{abstract}

(Kata kunci: Ampas kelapa, Aspergillus niger, Fermentasi)

\section{ABSTRACT}

This research was aimed to observe the effect of usage of Aspergillus niger for fermenting coconut dregs (Cocos nucifera L.) on its nutrition quality. Aspergillus niger obtained from Biochemical and Nutrition Laboratory of Animal Science Faculty on UGM, Yogyakarta was optimalized at coconut oil and coconut dregs as substrat. Variable was perceived for example enzyme lipase production, the quality of physical $(\mathrm{pH}$, texture, color, aroma), and chemical composition of coconut dregs, steamed coconut dregs, fermented coconut dregs and steamed fermented coconut dregs. The result showed that Aspergillus niger producted highest enzyme of lipase in four days incubation either at coconut oil $(0.85 \mathrm{U} / \mathrm{ml})$ and coconut dregs $(1.81 \mathrm{U} / \mathrm{ml})$ as substrat. The treatment of steaming and fermenting of coconut dregs affected of $\mathrm{pH}$, tekstur, color, aroma as will as decreased dry materials (12.75 and 16.24\%), crude fat (13.11 and $29.20 \%$ ), organic materials (5.21 and $16.89 \%)$ but increased crude protein (11.84\%), crude fibre (24.85 and $36.81 \%)$ and extract materials without nitrogen (10.28 and $23.97 \%)$. It could be concluded that Aspergillus niger have activity of lipase which high enough so that can degraded fat content of coconut dregs.

(Key words: Aspergillus niger, Coconut dregs, Fermentation)

\section{Pendahuluan}

Harga bahan pakan yang cenderung meningkat dan tidak diimbangi dengan kenaikan harga produk peternakan dapat menurunkan kinerja industri peternakan. Dalam industri peternakan, pakan merupakan $60-70 \%$ dari total biaya produksi (Murtidjo, 1987) maka perlu dicari komponen

\footnotetext{
* Korespondensi (corresponding author):

Telp. +62 85641470132

E-mail: kurniawan.byl@gmail.com
}

pakan alternatif yang lebih efisien secara ekonomi dan memperbaiki performa ternak. Ampas kelapa banyak ditemukan di Kecamatan Ampel, Kabupaten Boyolali Provinsi Jawa Tengah, yang merupakan limbah industri pembuatan abon. Industri pembuatan abon menggunakan 15 butir kelapa untuk pembuatan 1 kuintal abon dan dalam satu hari, satu perusahaan abon memproduksi abon rerata sebanyak 5 kuintal. Ampas kelapa dapat digunakan 
sebagai pakan alternatif, karena memiliki kandungan nutrien yang cukup yaitu protein $5,78 \%$; lemak $38,24 \%$ dan serat kasar 15,07\% (Putri, 2010). Mengingat kandungan lemak ampas kelapa yang terlalu tinggi dapat mengganggu fermentasi bahan pakan didalam rumen.

Penambahan ampas virgin coconut oil (VCO) dalam ransum domba sebesar 10, 20 dan $30 \%$ dari pakan basal berupa konsentrat dan hijauan menghasilkan kadar ekstrak eter (EE) ransum sebesar 6,984; 10,968 dan $14,952 \%$, dapat menurunkan konsumsi pakan karena kandungan lemak pada ampas VCO masih terlalu tinggi (Utomo et al., 2007). Church (1976) menyatakan pemberian lemak pada ransum ruminansia tidak boleh melebihi 4\% sedangkan Freer dan Dove (2002) menyatakan bahwa batas pemberian lemak pada pakan domba 5-6\%. Lemak yang berlebihan dapat mengganggu fermentasi rumen dan mengurangi pencernaan serat (Hristov et al., 2009; Vafa et al., 2009). Hobson dan Stewart (1997) menyatakan lemak akan melapisi mikroorganisme dengan sebuah lapisan hydrofobik sehingga menghambat metabolisme dan juga mengganggu bakteri pencerna selulosa, dengan demikian menghambat hidrolisis selulosa.

Kadar lemak ampas kelapa dapat diturunkan dengan proses fermentasi menggunakan enzim lipase yang dihasilkan oleh Aspergillus niger (A. niger). Aktivitas maksimum lipase $A$. níger $1,46 \mathrm{IU} / \mathrm{ml}$, diperoleh dari media fermentasi yang mengandung glukosa $2 \%$ dan minyak zaitun $2 \%$ di bawah kondisi 1 vvm dan $450 \mathrm{~m}^{-1}$ (Falony et al., 2006). Aktivitas lipase paling tinggi $(14,4 \mu / \mathrm{ml})$ pada inkubasi hari ke enam dengan penambahan $3 \%$ minyak zaitun (sumber karbon) serta optimum pada $\mathrm{pH} 6,5$ dan temperatur $40^{\circ} \mathrm{C}$ (Brooks dan Asamudo, 2011). Mohseni et al. (2012) menyatakan aktivitas lipase $A$. niger dengan substrat dedak padi yang diinkubasi selama 4 hari pada temperatur $35^{\circ} \mathrm{C}$ dan kelembapan tempat inkubasi 90\% sebesar 142.732 U/gds. Penelitian ini bertujuan untuk mengetahui pengaruh penggunaan $A$. niger untuk fermentasi ampas kelapa terhadap kualitas nutrisi ampas kelapa. Dari hasil penelitian ini diharapkan ampas kelapa fermentasi sebagai komponen pakan alternatif ruminansia yang dapat meningkatkan efisiensi biaya pakan.

\section{Materi dan Metode}

\section{Optimalisasi produksi enzim lipase}

Produksi enzim lipase. Medium inokulum dibuat dengan mencampurkan 0,13 $\mathrm{g}$ potato broth agar, $4,87 \mathrm{ml}$ aquadest dan $0,1 \mathrm{ml}$ minyak kelapa (Falony et al., 2006) dengan modifikasi. Medium dihomogenkan dengan menggunakan fortex lalu disterilkan menggunakan autoclave. Setelah medium tidak panas (hangat), ditambahkan rifampicin $0,0003 \mathrm{~g}$ dan $0,51 \mathrm{ml}$ biakan $A$. niger. Kemudian medium dan inokulum dihomogenkan menggunakan fortex lalu diinkubasi pada suhu ruang selama 2, 3, 4 dan 5 hari. Setiap perlakuan, memiliki ulangan sebanyak 3 kali.

Fermentasi padat. Ampas kelapa sebanyak $10 \mathrm{~g}$ yang telah diangin-anginkan semalam dimasukkan ke dalam tabung erlenmeyer yang telah disterilkan menggunakan autoclave. Tabung erlenmeyer yang berisi ampas kelapa ditambahkan aquadest agar kadar air menjadi $70 \%$ dan diinokulasi dengan $A$. niger sebesar 0,324 ml, dan dihomogenkan. Proses inkubasi dilakukan pada suhu ruang selama 3, 4, 5, 6 dan 7 hari. Setiap perlakuan dilakukan ulangan sebanyak 3 kali.

Ekstraksi enzim. Setelah massa inkubasi berakhir, ampas kelapa fermentasi dipanen dengan menambahkan $20 \mathrm{ml}$ aquadest dan dihomogenkan, kemudian disaring menggunakan kain kassa sehingga didapatkan cairan ampas kelapa fermentasi. Cairan ampas kelapa fermentasi disentrifus 3.000 rpm selama 15 menit sehingga didapatkan filtrat yang digunakan sebagai sumber enzim untuk analisis aktivitas lipase.

Uji aktivitas lipase. Aktivitas enzim lipase ditentukan menggunakan metode emulsi substrat minyak zaitun (Adinarayana et al., 2004). Pertama-tama membuat emulsi substrat minyak zaitun sebanyak $1 \mathrm{ml}$ yang terdiri dari $0,7 \mathrm{ml}$ reagen emulsi $(\mathrm{NaCl} 17,9$ g, $\mathrm{KH}_{2} \mathrm{PO}_{4} 0,41 \mathrm{~g}$, gliserol $540 \mathrm{ml}$, gum arabic $10 \mathrm{~g}$ dan aquades $1 \mathrm{~L}$ ) dicampurkan dengan 0,3 $\mathrm{ml}$ minyak zaitun, kemudian diaduk menggunakan vortex selama 5 menit. Setelah itu, $1 \mathrm{ml}$ substrat minyak zaitun dicampurkan dengan $0,8 \mathrm{ml} \mathrm{0,2} \mathrm{M}$ potasium buffer phospat ( $\mathrm{pH}$ 7) dan 0,2 ml ekstrak enzim, kemudian diinkubasi pada suhu $55^{\circ} \mathrm{C}$ selama 30 menit. Reaksi dihentikan dengan penambahan $2 \mathrm{ml}$ campuran aseton etanol $(1: 1 \mathrm{v} / \mathrm{v})$. Hasil hidrolisis enzim lipase ditentukan dengan cara titrasi menggunakan $0,01 \mathrm{~N} \mathrm{NaOH}$. Hasil uji aktivitas lipase 
digunakan untuk memilih inokulum yang digunakan untuk fermentasi ampas kelapa.

\section{Fermentasi ampas kelapa}

Proses pengukusan. Ampas kelapa segar yang telah diangin-anginkan semalam dikukus menggunakan panci kukus. Pengukusan ampas kelapa dilakukan selama 15 menit setelah air yang terdapat pada dasar panci kukus mendidih.

Proses fermentasi. Ampas kelapa yang dikukus maupun yang tidak dikukus sebanyak $1 \mathrm{~kg}$ dicampur dengan inokulum A. niger 3,248 $\mathrm{ml}$ (Falony et al., 2006). Inkubasi ditempatkan di dalam kantong plastik dengan ketebalan ampas kelapa $2 \mathrm{~cm}$ dan diinkubasikan pada suhu ruangan selama 4 hari. Ampas kelapa fermentasi dikeringkan dengan menggunakan oven $55^{\circ} \mathrm{C}$. Setelah kering, sampel masing-masing perlakuan digiling. Masing-masing perlakuan memiliki ulangan sebanyak 3 kali.

\section{Pengujian sampel}

Dari sampel masing-masing perlakuan optimalisasi enzim lipase dilakukan uji aktivitas lipase, sedangkan pada perlakuan pengukusan, fermentasi dan kukus fermentasi dilakukan uji kualitas fisik dan komposisi kimia. Uji kualitas fisik berupa bau, tekstur, warna dan $\mathrm{pH}$. Analisis proksimat digunakan untuk mengetahui komposisi kimia ampas kelapa fermentasi (mengikuti prosedur AOAC, 2005). Analisis ini meliputi bahan kering (BK), protein kasar (PK), serat kasar (SK), lemak kasar (LK) dan abu, kemudian dari hasil analisis tersebut akan dilanjutkan untuk menentukan BETN.

\section{Analisis data}

Data optimasi aktivitas lipase yang diulang 3 kali dianalisis dengan analisis keragaman sesuai dengan rancangan acak lengkap pola searah agar diketahui pengaruh lama inkubasi terhadap aktivitas enzim lipase pada substrat potato glucose agar dan ampas kelapa. Data komposisi kimia hasil fermentasi yang diulang 3 kali dianalisis dengan analisis variansi sesuai dengan rancangan acak lengkap pola faktorial agar diketahui pengaruh perlakuan pengkukusan, fermentasi dan kukus fermentasi. Jika terdapat interaksi maka diuji lanjut menggunakan Duncan's new Multiple Range Test untuk mengetahui beda antar rerata (Sastrosupadi, 2000).

\section{Hasil dan Pembahasan}

\section{Aktivitas lipase inokulum}

Hasil analisis variansi menunjukkan bahwa perbedaan lama waktu inkubasi berpengaruh secara sangat nyata $(P<0,01)$ terhadap aktivitas enzim lipase (Tabel 1). Aktivitas lipase $A$. niger tertinggi pada inkubasi hari ke empat $(0,85 \mathrm{U} / \mathrm{ml})$. Pera et al. (2006) menyatakan aktivitas $A$. niger pada medium potato glucose agar yang ditambahkan mineral, menghasilkan aktivitas lipase tertinggi pada hari keempat, sedangkan Falony et al. (2006) menyatakan aktivitas lipase $A$. niger tertinggi dalam potato dextrose agar yang ditambahkan $2 \%$ minyak kelapa dan diinkubasi dalam suhu $37^{\circ} \mathrm{C}$ selama 48 jam.

Pada inkubasi hari keempat, $A$. niger mengalami fase pertumbuhan log atau eksponential karena $A$. niger menghasilkan enzim lipase yang tertinggi dibandingkan dengan lama waktu inkubasi hari ke 2, 3, dan 5. Toscano et al. (2011) menyatakan A. niger yang ditumbuhkan pada medium tributirin agar yang ditambahkan minyak minyak zaitun dan mineral, memiliki aktivitas lipase tertinggi $(15,5 \mathrm{U} / \mathrm{ml})$ pada akhir fase pertumbuhan eksponential. Hogg (2005) menyatakan bahwa pada fase log, mikrobia menghasilkan enzim untuk mensintesis subtrat dan pada kondisi yang optimal populasi sel mikrobia akan mengganda.

Tabel 1. Aktivitas enzim lipase inokulum $A$. niger $(\mathrm{U} / \mathrm{ml})$ (activity lipase enzyme of inokulum $A$. niger $(U / \mathrm{ml})$ )

\begin{tabular}{ccccc}
\hline \hline Lama Inkubasi (duration of Inkubation) & \multicolumn{3}{c}{$\begin{array}{c}\text { Rerata } \\
\text { (average) }\end{array}$} \\
\cline { 2 - 5 } & 1 & 2 & 0,50 & $0,52 \pm 0,02^{\mathrm{a}}$ \\
2 & 0,53 & 0,52 & $0,61 \pm 0,10^{\mathrm{b}}$ \\
3 & 0,62 & 0,60 & 0,62 & $0,85 \pm 0,04^{\mathrm{c}}$ \\
5 & 0,88 & 0,81 & 0,88 & $0,67 \pm 0,06^{\mathrm{b}}$ \\
\hline a,b,c Superskrip yang berbeda menunjukkan perbedaan yang sangat nyata (P<0,01) (different superscripts indicate \\
significantly different (P<0.01).
\end{tabular}




\section{Aktivitas lipase Aspergillus niger pada substrat ampas kelapa}

Hasil analisis variansi menunjukkan bahwa perbedaan lamanya waktu inkubasi ampas kelapa fermentasi (AKF) menggunakan $A$. niger sangat berpengaruh terhadap aktivitas enzim lipase $(P<0,01)$. Enzim lipase yang dihasilkan $A$. niger tertinggi pada hari keempat yaitu sebesar $1,81 \mathrm{U} / \mathrm{ml}(420 \mathrm{U} / \mathrm{g}$ enzim) (Tabel 2). Adinarayana et al. (2004) menyatakan fermentasi bungkil kelapa menggunakan Aspergillus pada inkubasi hari keempat memiliki aktivitas lipase tertinggi sebesar 620 U/g enzim. Tingginya aktivitas lipase pada penelitian Adinarayana et al. (2004) karena pada proses fermentasi ditambahkan mineral seperti $\left(\mathrm{NH}_{4}\right)_{2} \mathrm{SO}_{4}, \quad \mathrm{Na}_{2} \mathrm{HPO}_{4}$, $\mathrm{KH}_{2} \mathrm{PO}_{4}, \quad \mathrm{MgSO}_{4} .7 \mathrm{H}_{2} \mathrm{O}$, dan $\mathrm{CaCl}_{2}$. Penambahan mineral besi dan magnesium pada substrat menggunakan kapang Trichoderma sp. dan $A$. niger menghasilkan aktivitas enzim carboxyl methyl cellulose (cmc-ase) yang lebih tinggi dibandingkan dengan perlakuan penambahan mineral $\mathrm{Fe}$, $\mathrm{Mg}$ dan kontrol (Kusmiati dan Agustini, 2010). Adam dan Ahmed (2009) menyatakan bahwa penambahan $\mathrm{Ca}^{2+}$ dan $\mathrm{Mn}^{2+}$ menstimulasi aktivitas lipase tertinggi pada A. niger NRRL3. Penambahan mineral pada substrat dapat meningkatkan aktivitas enzim suatu mikrobia dikarenakan dalam menghasilkan enzim, mikrobia juga memerlukan mineral makro maupun mikro. Salminen dan Von- Wright (1993) menyatakan metabolisme pada mikrobia membutuhkan mineral sebagai aktivator enzim seperti $\mathrm{Mn} 2+, \mathrm{Mg} 2+$, Ca2+ dan lainnya.

\section{Pengujian kualitas fisik}

Hasil uji kualitas fisik menunjukkan bahwa fermentasi ampas kelapa yang tidak dikukus maupun dikukus menyebabkan perubahan bau, warna dan tekstur (Tabel 3). Perubahan bau disebabkan karena perombakan senyawa komplek dari karbohidrat menjadi senyawa sederhana yang mudah larut. Tekstur dan warna ampas kelapa sebelum dan sesudah dikukus mengalami perubahan karena pengkukusan menyebabkan pelebaran pori-pori ampas kelapa sehingga kadar air meningkat dan tekstur menjadi lembut. Pada fermentasi ampas kelapa, misellia $A$. niger yang berwarna hitam mengakibatkan perubahan warna ampas kelapa dan enzim selulase yang dihasilkan $A$. niger membuat tekstur ampas kelapa menjadi lebih lembut karena enzim selulase dapat mengubah selulosa menjadi glukosa.

Tabel 2. Aktivitas enzim lipase ampas kelapa fermentasi menggunakan A. niger $(\mathrm{U} / \mathrm{ml})$ (activity lipase enzyme of coconut dregs fermentation by $A$. niger $(\mathrm{U} / \mathrm{ml})$ )

\begin{tabular}{ccccc}
\hline \hline \multirow{2}{*}{ Lama Inkubasi (duration of Inkubation) } & \multicolumn{3}{c}{ Ulangan (replication) } & Rerata (average) \\
\cline { 2 - 4 } & 1 & 2 & 0,67 & $0,67 \pm 0,02^{\mathrm{a}}$ \\
\hline 3 & 0,69 & 0,65 & 1,77 & $1,81 \pm 0,04^{\mathrm{d}}$ \\
4 & 1,85 & 1,80 & $1,30 \pm 0,11^{\mathrm{c}}$ & $1,13 \pm 0,03^{\mathrm{b}}$ \\
5 & 1,24 & 1,42 & 1,24 & $1,10 \pm 0,03^{\mathrm{b}}$ \\
\hline 6 & 1,15 & 1,10 & 1,13 & 1,08 \\
a,b,c,d Superskrip yang berbeda menunjukkan perbedaan yang sangat nyata (P<0,01) (different superscripts indicate \\
significantly different $(P<0.01))$.
\end{tabular}

Tabel 3. Uji kualitas fisik ampas kelapa tanpa kukus dan kukus, tanpa fermentasi dan fermentasi menggunakan A. niger

(physical quality of coconut dregs with or without steamed, with or without fermented by A. niger)

\begin{tabular}{|c|c|c|c|c|}
\hline \multirow{2}{*}{$\begin{array}{l}\text { Variabel } \\
\text { (variable) }\end{array}$} & \multicolumn{2}{|c|}{$\begin{array}{l}\text { Ampas kelapa tanpa kukus } \\
\text { (coconut dregs not steamed) }\end{array}$} & \multicolumn{2}{|c|}{$\begin{array}{c}\text { Ampas kelapa kukus } \\
\text { (coconut dregs steamed) }\end{array}$} \\
\hline & $\begin{array}{l}\text { Tanpa fermentasi } \\
\text { (not fermented) }\end{array}$ & $\begin{array}{l}\text { Fermentasi } \\
\text { (fermented) }\end{array}$ & $\begin{array}{l}\text { Tanpa fermentasi } \\
\text { (not fermented) }\end{array}$ & $\begin{array}{l}\text { Fermentasi } \\
\text { (fermented) }\end{array}$ \\
\hline $\mathrm{pH}$ & 6,43 & 5,67 & 5,9 & 2,43 \\
\hline Warna (color) & Putih (white) & $\begin{array}{l}\text { Coklat muda (light } \\
\text { brown) }\end{array}$ & Putih (white) & $\begin{array}{l}\text { Hitam dan kuning } \\
\text { (black and yellow) }\end{array}$ \\
\hline Bau (smell) & Sedap (tasty) & $\begin{array}{l}\text { Cukup asam (enough } \\
\text { acid) }\end{array}$ & $\begin{array}{l}\text { Lebih sedap (more } \\
\text { tasty) }\end{array}$ & Asam (acid) \\
\hline $\begin{array}{l}\text { Tekstur } \\
\text { (texture) }\end{array}$ & $\begin{array}{l}\text { Lembut, berair } \\
\text { (soft, watery) }\end{array}$ & $\begin{array}{l}\text { Lebih lembut, lebih } \\
\text { Berlendir (more soft, } \\
\text { more mucus) }\end{array}$ & $\begin{array}{l}\text { Lembut, lebih berair } \\
\text { (soft, more watery) }\end{array}$ & $\begin{array}{l}\text { Lembut, berlendir } \\
\text { (soft, mucus) }\end{array}$ \\
\hline
\end{tabular}


Pengukusan maupun fermentasi ampas kelapa dengan menggunakan $A$. niger menyebabkan penurunan $\mathrm{pH}$ ampas kelapa sebesar 8,24 dan 11,82\%. Perlakuan kukus fermentasi juga menurunkan $\mathrm{pH}$ ampas kelapa sebesar 58,81\% (Tabel 3). Rendahnya $\mathrm{pH}$ pada ampas kelapa kukus fermentasi kemungkinan diakibatkan oleh banyaknya kandungan asam lemak dalam ampas kelapa fermentasi yang merupakan hasil degradasi lemak ampas kelapa.

\section{Pengujian kualitas kimia}

Bahan kering. Pengukusan maupun fermentasi ampas kelapa menyebabkan penurunan BK ampas kelapa secara sangat nyata $(P<0,01)$ dan terdapat interaksi antara pengukusan dan fermentasi $(P<0,01)$ terhadap penurunan kandungan $\mathrm{BK}$ ampas kelapa (Tabel 4). Proses pengukusan menyebabkan air yang berasal dari uap air meningkatkan kandungan kadar air ampas kelapa akibatnya kandungan BK ampas kelapa menurun. Subhan et al. (2010) menyatakan bahwa sagu yang dikukus dengan suhu $120^{\circ} \mathrm{C}$ selama 30 menit menyebabkan penurunan kandungan BK, sedangkan pada proses fermentasi, BK ampas kelapa dimanfaatkan oleh $A$. niger sebagai sumber energi. Proses fermentasi berlangsung secara baik jika terjadi serangkaian reaksi biokimiawi yang merubah BK menjadi energi (panas), molekul air $\left(\mathrm{H}_{2} \mathrm{O}\right)$ dan $\mathrm{CO}_{2}$ sehingga proses ini menyebabkan terjadinya penurunan kadar BK (Fardiaz, 1987).

Bahan organik. Pengukusan maupun fermentasi ampas kelapa menurunkan kandungan $\mathrm{BO}$ ampas kelapa $(\mathrm{P}<0,01)$. Interaksi antara pengukusan dan fermentasi memberikan pengaruh sangat nyata terhadap penurunan kandungan BO ampas kelapa $(P<0,01)$ (Tabel 4). Pada proses pengukusan mengalami penguapan sehingga kandungan nutrisi ampas kelapa mengalami perubahan akibatnya terjadi penurunan BK dan BO ampas kelapa. Susanti (2000) menyatakan bahwa jerami kedelai yang dikukus dapat menyebabkan penurunan kandungan $\mathrm{BK}$ dan $\mathrm{BO}$ jerami kedelai akibat merenggangnya ikatan konstituen dinding sel sehingga molekul sederhana dapat melewati dinding sel dan terlarut dalam air. Fermentasi ampas kelapa menyebabkan penurunan kandungan BO ampas kelapa yang diikuti penurunan BK ampas kelapa yang dimanfaatkan oleh $A$. niger sebagai sumber energi. Penurunan BK diikuti dengan penurunan kadar BO akibat terjadi serangkaian reaksi biokimiawi yang mengubah BK menjadi energi (panas), molekul air $\left(\mathrm{H}_{2} \mathrm{O}\right)$ dan $\mathrm{CO}_{2}$, sehingga proses ini menyebabkan terjadinya penurunan kadar abu substrat yang digunakan (Fardiaz, 1987).

Lemak kasar. Pengukusan maupun fermentasi ampas kelapa menurunkan kandungan LK ampas kelapa $(P<0,01)$. Interaksi antara pengukusan dan fermentasi berpengaruh sangat nyata $(P<0,01)$ terhadap penurunan kandungan LK ampas kelapa (Tabel 4). Pada proses pengukusan terjadi penguapan sehingga membuat lemak ampas kelapa menguap dan pori-pori ampas kelapa menjadi lebar akibatnya kinerja enzim lipase A. niger dapat secara optimal. Enzim lipase yang dihasilkan $A$. niger dapat memecah lemak menjadi asam lemak dan gliserol, kemudian asam lemak dan gliserol digunakan oleh $A$. niger sebagai sumber energi untuk proses pertumbuhannya. Purwadaria et al. (1995) melaporkan bahwa fermentasi bungkil kelapa kukus dengan menggunakan $A$. niger selama 4 hari dapat menurunkan kandungan LK sebesar $63,89 \%$.

Protein kasar. Pengukusan ampas kelapa tidak berpengaruh terhadap kandungan PK ampas kelapa, sedangkan fermentasi meningkatkan kandungan PK ampas kelapa $(\mathrm{P}<0,05)$. Interaksi antara pengukusan dan fermentasi memberikan pengaruh secara nyata $(P<0,05)$ terhadap peningkatan kandungan $\mathrm{PK}$ ampas kelapa (Tabel 4). Pada proses pengukusan, lama pengukusan ampas kelapa hanya selama 15 menit sehingga tidak terjadi perubahan kandungan protein. Subhan et al. (2010) melaporkan bahwa sagu yang dikukus dengan suhu $120^{\circ} \mathrm{C}$ selama 30 menit tidak menyebabkan perubahan kandungan PK sagu. Peningkatan PK ampas kelapa fermentasi diakibatkan oleh adanya enzimenzim yang diproduksi oleh $A$. niger seperti enzim protease, lipase, amilase, selulase, glukoamilase, hemiselulase, pektinase, oksidase dan katalase. Enzim yang dihasilkan tersebut dapat mengubah susunan senyawa-senyawa dalam ampas kelapa fermentasi sehingga terjadi perubahan komposisi kimia ampas kelapa. Fermentasi dapat menimbulkan perubahan sifat bahan pakan sebagai akibat pemecahan kandungan zat makanan oleh aktivitas enzim yang dihasilkan mikroba dan disebabkan oleh turunnya BO selama proses fermentasi sebagai akibat dari terombaknya beberapa 
Tabel 4. Komposisi kimia ampas kelapa tanpa kukus dan kukus, tanpa fermentasi dan fermentasi menggunakan $A$. niger (\%BK)

(chemical composition of coconut dregs with or without steamed, with or without fermented by $A$. niger (\%BK))

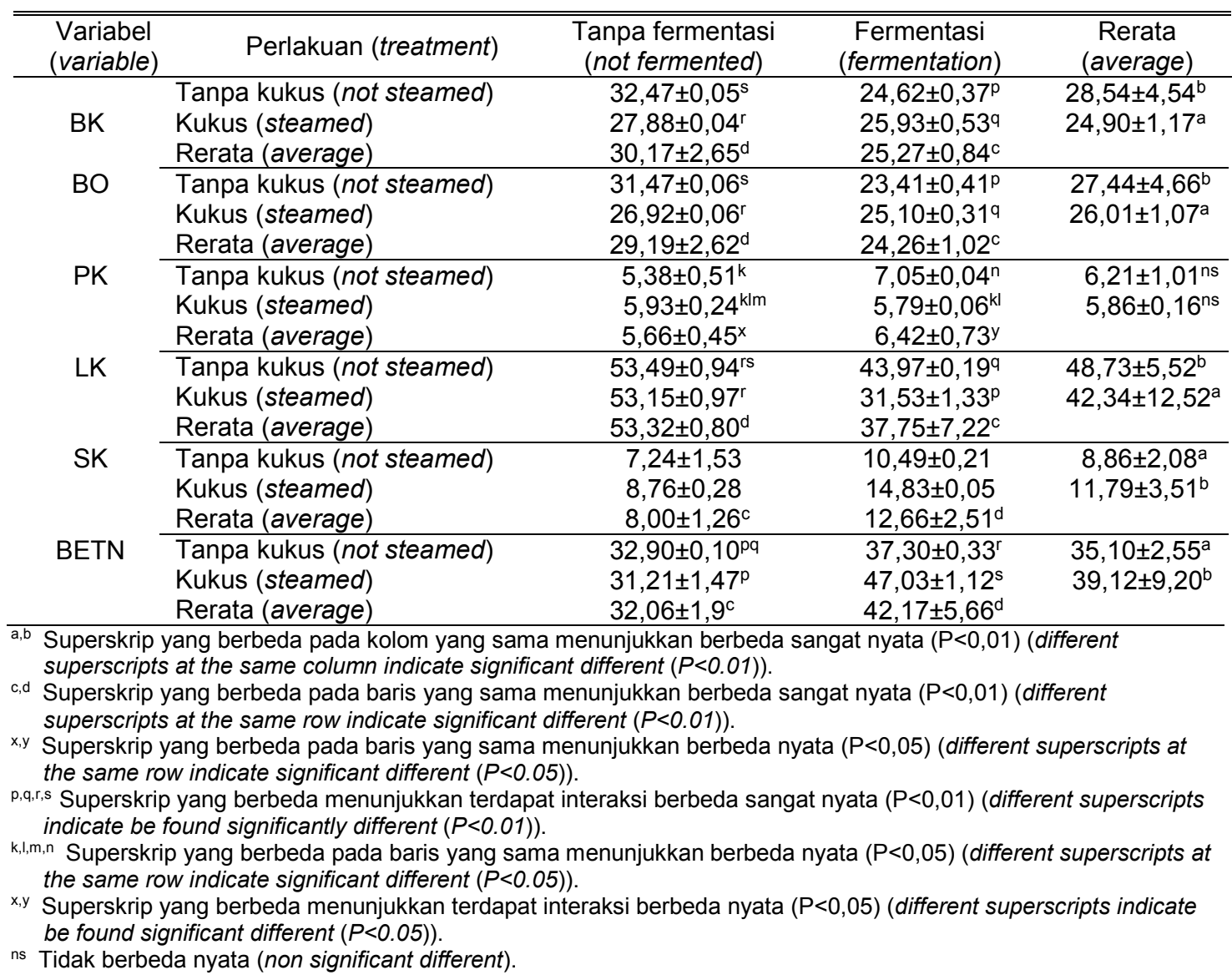

zat makanan seperti karbohidrat, lemak serta protein (Sjofjan, 2001). Hal ini sejalan dengan hasil penelitian Mairizal (2009), kapang $A$. niger memiliki kemampuan untuk meningkatkan protein bahan dari hasil enzim proteolitik dalam menghidrolisis protein menjadi asam amino dan sumbangan dari protein sel tunggalnya.

Serat kasar. Pengukusan maupun fermentasi ampas kelapa memberikan pengaruh yang sangat nyata $(P<0,01)$ terhadap peningkatan kandungan SK ampas kelapa (Tabel 4). Pada proses pengukusan mengalami penguapan sehingga mengakibatkan perubahan komposisi nutrisi ampas kelapa seperti penurunan kandungan LK ampas kelapa yang dapat mengubah susunan senyawa-senyawa kimia dalam ampas kelapa kukus akibatnya terjadi perubahan komposisi kimia ampas kelapa.

Peningkatan SK ampas kelapa disebabkan perubahan kandungan nutrisi ampas kelapa seperti penurunan LK dan BO serta peningkatan PK ampas kelapa yang dapat mengubah susunan senyawa-senyawa dalam ampas kelapa fermentasi sehingga terjadi perubahan komposisi kimia ampas kelapa.

Peningkatan SK ampas kelapa fermentasi juga dapat disebabkan oleh dinding misellia $A$. niger. Misellia yang subur dapat menguraikan fraksi serat tetapi pada dinding misellia $A$. niger mengandung SK yang tinggi, sehingga merupakan sumbangsih SK terhadap media yang difermentasi. Kandungan SK AKK fermentasi pada penelitian ini lebih tinggi dibandingkan hasil penelitian Mirwandhono dan Siregar (2004), fermentasi lumpur sawit menggunakan $A$. niger selama 4 hari meningkatkan SK sebesar 8,19\%. Munir (2012) menyatakan bahwa $A$. niger yang digunakan untuk fermentasi kulit buah kakao dengan ukuran yang tidak beraturan dapat meningkatkan kandungan SK kulit buah kakao pada hari ke $5(7,67 \%)$ dan $7(5,73 \%)$ 
tetapi kandungan SK menurun pada hari ke 9 $(0,61 \%)$. Hal ini mungkin disebabkan oleh tingginya pertumbuhan jamur dan kematangan pertumbuhan miselia $A$. niger yang ditandai dengan lebatnya miselia jamur dan berwarna hitam.

Bahan ekstrak tanpa nitrogen (BETN). Pengukusan maupun fermentasi ampas kelapa meningkatkan kandungan BETN ampas kelapa $(P<0,01)$. Interaksi antara pengukusan dan fermentasi berpengaruh sangat nyata $(P<0,01)$ terhadap peningkatan kandungan BETN ampas kelapa (Tabel 4). Peningkatan BETN disebabkan karena pada pengukusan mengalami proses penguapan sehingga mengakibatkan nutrisi yang terkandung dalam ampas kelapa mengalami perubahan khususnya kandungan LK akibatnya terjadi peningkatan kandungan karbohidrat dalam ampas kelapa. Subhan et al. (2010) melaporkan sagu yang dikukus dengan suhu $120^{\circ} \mathrm{C}$ selama 30 menit meningkatkan kandungan BETN sagu kukus $(P<0,01)$.

Fermentasi ampas kelapa dapat meningkatkan kandungan BETN karena $A$. niger memanfaatkan lemak ampas kelapa dengan cara dihidrolisis menggunakan enzim lipase yang dihasilkannya menjadi asam lemak dan gliserol. Gliserol yang dihasilkan sebagian digunakan oleh kapang sebagai sumber energi. Hal ini dapat dilihat didalam Tabel 4 bahwa semakin tinggi penurunan kandungan LK maka semakin tinggi kandungan BETN. Supriatna (2005) menyatakan bahwa fermentasi kulit buah markisa dengan menggunakan $A$. niger dapat menurunkan kandungan LK 3,8\% dan meningkatkan kandungan BETN 44\%.

\section{Kesimpulan}

Berdasarkan hasil penelitian, dapat diambil kesimpulan bahwa $A$. niger memproduksi enzim lipase tertinggi pada masa inkubasi hari ke empat baik pada substrat minyak kelapa maupun ampas kelapa dan apabila digunakan untuk fermentasi ampas kelapa dapat mengubah komposisi nutrien ampas kelapa khususnya penurunan kandungan lemak.

\section{Daftar Pustaka}

Adam, N. Z. and E. M. Ahmed. 2009. Extracellular lipase of Aspergillus niger NRRL3; production, partial purification and properties. Indian J. Microbiol. 49: 77-83.

Adinarayana, K., K. V. V. S. N. B. Raju, M. I. Zargar, R. B. Devi, P. J. Lakshmi and P. Ellaiah. 2004. Optimization of process parameters for production of lipase in solid-state fermentation by newly isolated Aspergillus species. Pharmaceutical Biotechnology Division, Department of Pharmaceutical Sciences, Andhra University, Visakhapatnam. 3: 65-69.

AOAC. 2005. Official methods of analysis of the assosiation of official agricultural chemist. Published by the Association of Official Analytical Chemists, Maryland, USA.

Brooks, A. A. and N. U. Asamudo. 2011. Lipase production by strains of Aspergillus species isolated from contaminated body creams. J. Toxicol. Environ. Health Sci. 3: 311-316.

Church, D. C. 1976. Digestive Physiology and Nutrition of Ruminants. Vol. 1: Digestive Physiology. $2^{\text {nd }}$ edn. Metropolitan Printing Co., Corvallis, OR.

Falony, G., J. C. Armas, J. C. D. Mendoza and J. L. M. Hernandez. 2006. Production of extracellular lipase from Aspergillus niger by solid-state fermentation. Food Technol. Biotechnol, Mexico. 44: 235-240.

Fardiaz, S. 1987. Fisiologi Fermentasi. Pusat Studi, Institut Pertanian Bogor dengan Lembaga Sumberdaya Informasi Institut Pertanian Bogor, Bogor.

Freer, M. and H. Dove. 2002. Sheep Nutrition. Cabi Publishing, Australia.

Hobson, P. N. and C. S. Stewart. 1997. The Rumen Microbial Ecosystem. Blackie Academic \& Professional, London.

Hogg, S. 2005. Essential Microbiology. John Wiley \& Sons Ltd, England.

Hristov, A. N., P. M. Vander, M. Agle, S. Zaman, and C. Schneider. 2009. Effect of lauric acid and coconut oil on ruminal fermentation, digestion, ammonia losses from manure, and milk fatty acid composition in lactating cows. J. Dairy Sci. 92: 5561-5582.

Kusmiati dan N. W. S. Agustini. 2010. Pemanfaatan limbah onggok untuk produksi asam sitrat dengan penambahan mineral Fe dan Mg pada substrat menggunakan kapang Trichoderma sp. dan Aspergillus niger. Seminar Nasional Biologi. Fakultas 
Biologi, Universitas Gadjah Mada, Yogyakarta.

Mairizal. 2009. Pengaruh pemberian kulit ari biji kedelai hasil fermentasi dengan Aspergillus niger sebagai pengganti jagung dan bungkil kedelai dalam ransum terhadap retensi bahan kering, bahan organik dan serat kasar pada ayam pedaging. Jurnal IImiah IImuilmu Peternakan 12: 35-40.

Mirwandhono, E. dan Z. Siregar. 2004. Pemanfaatan hidrolisat tepung kepala udang dan limbah kelapa sawit yang difermentasi dengan Aspergillus niger, Rhizopus oligosporus dan Trichoderma viridae dalam ransum ayam pedaging. Fakultas Pertanian, Universitas Sumatera Utara, Medan.

Mohseni, S., G. D. Najafpour, Z. Vaseghi and S. Mahjoub. 2012. Solid state fermentation of agricultural residues for lipase production in a traybioreactor. World Appl. Sci. 16: 10341039.

Munir, F. F. 2012. Kajian fermentasi kulit buah kakao (Theobroma cacao L.) menggunakan Aspergillus spp. terhadap kecernaan dan konsumsi pada kambing peranakan etawah jantan. Disertasi, Universitas Gadjah Mada, Yogyakarta.

Murtidjo, B. A. 1987. Pedoman Beternak Ayam Broiler. Kanisius, Yogyakarta.

Pera, L. M., C. M. Romero, M. D. Baigori and G. R. Castro. 2006. Catalytic properties of lipase extracts from Aspergillus niger. Food Technol. Biotechnol. 44: 247-252.

Purwadaria, T., T. Haryati, J. Darma and O. I. Munazat. 1995. In vitro digestibility evaluation of fermented coconut meal using Aspergillus niger NRRL 337. Balai Penelitian Ternak, Bogor.

Putri, M. F. 2010. Tepung ampas kelapa pada umur panen 11-12 bulan sebagai bahan pangan sumber kesehatan. Jurnal Kompetensi Teknik 1: 97-105.

Salminen, S. and A. Von-Wright. 1993. Lactic Acid Bacteria. Marcel Dekker, Inc. New York.
Sastrosupadi, A. 2000. Rancangan Percobaan Praktis Bidang Pertanian. Kanisius, Yogyakarta.

Subhan, A., T. Yuwanta, dan J. H. P. Sidadolong. 2010. Pengaruh penggunaan sagu kukus (Metroxylon spp) dan tepung keong mas (Pomacea spp.) sebagai pengganti jagung kuning dalam pakan terhadap penampilan itik jantan Alabio, Mojosari dan hasil persilangannya. Buletin Peternakan 34: 30-37.

Supriatna. 2005. Peningkatan kualitas gizi kulit buah markisa melalui proses fermentasi dengan Aspergillus niger sebagai bahan pakan ternak. Prosiding Temu Teknis Nasional Tenaga Fungsional Pertani, Galang, Sumatera Utara.

Susanti, E. 2000. Pengaruh pemasakan, pemeraman dalam asam fosfat, dan pemeraman dengan Aspergillus spp. jerami kedelai terhadap degradabilitas secara in sacco. Tesis Fakultas Peternakan, Universitas Gadjah Mada, Yogyakarta.

Sjofjan, O. 2001. Perubahan kandungan bahan organik dan protein pada fermentasi campuran onggok dan kotoran ayam. Jurnal IImu-ilmu Hayati 1: 1-7.

Toscano, L., G. Montero, M. Stoytcheva, H. Campbell and A. Lambert. 2011. Preliminary assessment of biodiesel generation from meat industry residues in Baja California, Mexico. Biomass and Bioenergy 35: 26-31.

Utomo, R., C. T. Noviandi, L. M. Yusiati, Rusman, dan I. I. Falah. 2007. Penggunaan Ampas Virgin Coconut Oil (VCO) sebagai pakan domba. Fakultas Peternakan UGM, Yogyakarta.

Vafa, T. S., A. A. Naserian and A. R. H. Moussavi. 2009. Effect of different levels of fish oil and canola oil on in vitro and in vivo nutrient digestibility. Res. Biol. Sci. 4: 1221-1226. 